\title{
NITROGEN FERTILIZER INFLUENCE ON WINTER WHEAT YIELD AND YIELD COMPONENTS DEPENDING ON SOIL TILLAGE AND FORECROP
}

\author{
Linda Litke, Zinta Gaile, Antons Ruža \\ Latvia University of Agriculture \\ linda_litke@inbox.lv
}

\begin{abstract}
Wheat (Triticum aestivum) is one of the main crops grown in Latvia. Nitrogen fertilizer is one of the most important factors affecting the acquired yield and its quality. The aim of this paper is to describe the nitrogen fertilization impact on winter wheat yield and yield components under two soil tillage systems and after two forecrops. Field trials were carried out at Research and Study farm 'Peterlauki' of Latvia University of Agriculture $\left(56^{\circ} 30.658^{\circ} \mathrm{C} \mathrm{N}\right.$ and $23^{\circ} 41.580^{\circ} \mathrm{C} \mathrm{E}$ ) in $2014 / 2015$ and $2015 / 2016$. Researched factors were (1) crop rotation (continuous wheat and wheat/oilseed rape (Brassica napus ssp. oleifera), (2) soil tillage (traditional soil tillage with mould-board ploughing at a depth of $22-24 \mathrm{~cm}$ and reduced soil tillage with disc harrowing at a depth below $10 \mathrm{~cm}$ ), and (3) nitrogen fertilizer rate (N0 or control, N60, N90, N120(90+30), N150(90+60), N180(90+60+30), N210 $(90+70+50)$, and $\mathrm{N} 240(120+60+60)$. Results showed that the nitrogen fertilization significantly increased winter wheat grain yield after both forecrops and in both soil tillage variants. Grain yield significantly increased until the nitrogen fertilizer rate N180. Nitrogen fertilizer significantly affected all tested yield components. Values of yield components increased enhancing N-rate of N150 - N180. The forecrop had a significant impact on wheat yield and 1000 grain weight (both increased when wheat was sown after oilseed rape). Yield and grain number per ear were significantly higher when conventional tillage was used, but number of ears per $\mathrm{m}^{2}$ - when the reduced tillage was used.
\end{abstract}

Key words: forecrop, soil tillage, nitrogen fertilizer, wheat yield, yield components.

\section{Introduction}

Wheat (Triticum aestivum) is one of the most important cereal crops in Latvia. In this country, the average statistical grain yield is around $4 \mathrm{t} \mathrm{ha}^{-1}$, therefore it is important to study production increase possibilities. High yield of good quality is based on the used agro-technical measures. One of the most important agro-technical measures is optimal nutrient provision. Nitrogen is a nutrient of high importance for plant growth, development, and grain quality assurance, but it is also one of the most mobile plant nutrients in the soil. Unsuitable nitrogen doses lead to increased nitrate leaching, which contributes to eutrophication of surface waters (Myrbeck, 2014).

A variety of methods are available to reduce the use of nitrogen fertilizer. One approach is to adopt a fertilizer-reducing farming practices. One of such measures can be crop rotation, for example, it is possible to include legumes in the crop rotation. Legumes are used to fix nitrogen as a substitute for artificial nitrogen fertilizer (Huang \& Uri, 1993). Nowadays farmers use a very short crop rotation with high proportion of cereals. They often sow cereals after cereals, in better case, cereals after oil crops. But resowings of cereals can lead to a grain yield decrease. The reasons of grain yield decrease are the increase of fungal diseases and weeds, and the degradation of soil structure, as well as negative impacts on water and air regime (Babulicová, 2014).

Frequently wheat growing in a short crop rotation or even without any rotation is combined with a reduced tillage. Soil tillage is an important operation of agricultural production technology. Researchers found that soil tillage can affect nitrogen leaching (Stenberg, 1998) and it can also affect crop yields. In literature, the results regarding the tillage effect on wheat yield are contrary: some authors (e.g., Lyon, Stroup, \& Brown, 1998) have concluded that a higher yield can be achieved by using conventional tillage (mouldboard ploughing) in comparison to non-conventional tillage systems, but others (e.g., Kosutic et al., 2005) indicate that a higher winter wheat yield is obtained using reduced soil tillage (chisel plough, multitiller) if compared with a traditional one, however, differences are not significant.

In Latvia, nitrogen influence on wheat yields has been much studied. For example, the latest previous studies on the effect of $\mathrm{N}$-fertilization rate with older winter wheat cultivars 'Bussard' and 'Zentos' showed that the grain yield increased until the N-rate of $120-150 \mathrm{~kg} \mathrm{ha}^{-1}$, but grain quality increased until the N-rate $180 \mathrm{~kg} \mathrm{ha}^{-1}$ (Ruža, Maļecka, \& Kreita, 2012). However, newer cultivars can react differently to such fertilizer rates. At the same time, Ministry of Agriculture depending on the planned size of grain yields, has developed rules determining the maximum allowable N-rate for winter wheat (until N $220 \mathrm{~kg} \mathrm{ha}^{-1}$ ) (Cabinet Regulations No. 834 (2014), retrieved from https://m.likumi.lv/doc.php?id=271376). Nowadays, reduced soil tillage is used more and more widely also in Latvia. Therefore, in Latvia, researchers and farmers are looking for cost-effective and environmentally friendly rates of $\mathrm{N}$-fertilizers in different tillage systems with different forecrops for winter wheat. The objective of this experiment was to clarify the nitrogen fertilization impact on winter wheat yield and 
yield components under two soil tillage systems and after two forecrops.

The research has been carried out within the framework of 'State and European Union investment for encouragement in agriculture' theme 'Determination of maximal fertiliser norms for crops'.

\section{Materials and Methods}

Three-factor field trials were conducted at Research and Study farm 'Peterlauki' of Latvia University of Agriculture $\left(56^{\circ} 30.658^{\circ} \mathrm{C} \mathrm{N}\right.$ and $\left.23^{\circ} 41.580^{\circ} \mathrm{C} \mathrm{E}\right)$ in the growing seasons of 2014/2015 and 2015/2016. Trials were arranged using split plot design in four replications. Researched factors were (1) crop rotation (wheat/wheat and wheat/oilseed rape (Brassica napus ssp. oleifera), (2) soil tillage (traditional soil tillage with mould-board ploughing at a depth of $22-24 \mathrm{~cm}$ and reduced soil tillage with disc harrowing at a depth below $10 \mathrm{~cm}$ ), and (3) nitrogen fertilizer rate (altogether eight rates: N0 or control, N60, N90, N120 $(90+30)$, $\mathrm{N} 150(90+60), \mathrm{N} 180(90+60+30), \mathrm{N} 210(90+70+50)$, and $\mathrm{N} 240(120+60+60))$. One of the most widely grown cultivars in Latvia 'Skagen' was used in the trial. It is characterized by a good winterhardiness which is combined with disease resistance and baking quality. Wheat was sown at the rate of 450 germinable seeds $\mathrm{m}^{-2}$ in the second half of September after both forecrops in 2015/2016 and after oilseed rape in 2014/2015. Due to adverse weather conditions, wheat sowing after wheat was delayed to the beginning of October in 2014/2015, and consequently, in this case, sowing rate was a little increased (500 germinable seed $\mathrm{m}^{-2}$ ). Soil at the site was loam, Endocalcaric Abruptic Luvisol (Cutanic, Hypereutric, Ruptic, Siltic, Protostagnic, Epiprotovertic). Soil is characterized by the following indicators depending on the year: $\mathrm{pH} \mathrm{KCL}=6.3-6.9$, organic matter content $2.3-$ $2.5 \mathrm{~g} \mathrm{~kg}^{-1}, \mathrm{P}$ content $30.1-107.7 \mathrm{mg} \mathrm{kg}^{-1}$ and $\mathrm{K}$ content $131.1-272.24 \mathrm{mg} \mathrm{kg}^{-1}$ of the soil. Before sowing, fertilizer was applied: P $17.44-19.18 \mathrm{~kg} \mathrm{ha}^{-1}$ and $\mathrm{K} 46.48-51.13 \mathrm{~kg} \mathrm{ha}^{-1}$. Weeds were controlled using herbicides in both years, but wheat diseases were controlled by fungicide application once per season (GS 51).

In spring, when the vegetation had renewed, nitrogen fertilizer $\left(\mathrm{NH}_{4} \mathrm{NO}_{3} ; \mathrm{N} 34 \%\right)$ was applied for all variants, except the control variant N0. The whole rate of fertilizer was applied in one time for variants $\mathrm{N} 60$ and N90, it was divided into two applications for variants N120 and N150, but into three applications for variants N180 - N240. Second top-dressing was done at GS $29-31$ of winter wheat, but the third - at GS $47-51$.

Plant sample sheets were taken before the yield harvesting at GS 89 for analysis of crop yield components from $0.12 \mathrm{~m}^{2}$ in each plot. The following yield components were detected: number of ears per $\mathrm{m}^{2}$, grain number per ear, 1000 grain weight $(\mathrm{g})$, grain weight per ear $(\mathrm{g})$. After harvesting the whole plots, yields' data was calculated to standard moisture (14\%) and $100 \%$ purity.

Meteorological conditions in trial years 2014/2015 and 2015/2016 were different from the long-term average data. The autumn of 2014 was long and cool, but in 2015, it was relatively warm and dry. Both winters were mild and favorable for wheat wintering. The vegetation renewed in mid-March in both years. Both springs were warm and favorable for the development of crop. Summer in 2015 was characterized by high rainfall only in July, but that of 2016 was overall very rainy. In general, weather conditions promoted growth and development, and high yield formation of wheat in both years, but 2014/2015 can be characterized as slightly more optimal.

For data statistical processing analysis of variance was used. Bonferroni test was used for comparison of means; the differences were considered statistically significant when $p<0.05$. Significantly different means were labeled with different letters (a,b,c,d,e,f,g,h or A, B) in superscript. Data processing was done using R-studio.

\section{Results and Discussion \\ Wheat yield}

Winter wheat grain yield was very high on average per two years $\left(8.12 \mathrm{t} \mathrm{ha}^{-1}\right)$. Without any nitrogen top-dressing it was $4.84 \mathrm{t} \mathrm{ha}^{-1}$, but in variants where nitrogen was applied it, depending on rate, was $6.85-9.71 \mathrm{t} \mathrm{ha}^{-1}$ (Table 1). Year as a factor did not significantly affect wheat yield (Table 2). The effect of the nitrogen fertilization on the wheat grain yield was the same in both years of study. Results show that nitrogen fertilization significantly increased the average grain yield per both years $(p<0.001$, Table 2$)$ if compared to control. $\mathrm{N}$-fertilization had the most impact on yield among all researched factors (Table 2). It coincides with another studies which demonstrated that nitrogen application significantly enhanced the grain yield (Ruža, Mal̦ecka, \& Kreita, 2012; Skudra, Ruža, 2014; Maadi et al., 2012). In our trial, even lower nitrogen fertilizer rates gave a significant yield increase if compared with N0 (control). A significant yield increase was observed until the nitrogen fertilizer rate N180 (Table 1).

Results show that the forecrop had a significant impact on the grain yield ( $<0.001$; Table 2$)$, and oilseed rape was a better forecrop for high winter wheat yield production. The average grain yield was higher $\left(+0.49 \mathrm{tha}^{-1}\right)$ in variant where the forecrop was oilseed rape $\left(4.83-9.98 \mathrm{tha}^{-1}\right)$, despite the fact that in the control variant (N0) winter wheat grain yields were similar after both forecrops (Table 1). Similar results 
Winter wheat yield depending on nitrogen fertilizer rate, forecrop and soil tillage, $t_{\text {ha }}{ }^{-1}$

\begin{tabular}{|l|c|c|c|c|c|}
\hline \multirow{2}{*}{ N-rate } & \multicolumn{2}{|c|}{ Forecrop } & \multicolumn{2}{c|}{ Soil tillage } & \multirow{2}{*}{ Average } \\
\cline { 2 - 5 } & Oilseed rape & Wheat & Traditional & Reduced & \\
\hline N0 & $4.83^{\mathrm{a}}$ & $4.85^{\mathrm{a}}$ & $5.11^{\mathrm{a}}$ & $4.55^{\mathrm{a}}$ & $4.84^{\mathrm{a}}$ \\
\hline $\mathrm{N} 60$ & $6.87^{\mathrm{b}}$ & $6.82^{\mathrm{b}}$ & $7.22^{\mathrm{b}}$ & $6.46^{\mathrm{b}}$ & $6.85^{\mathrm{b}}$ \\
\hline $\mathrm{N} 90$ & $7.63^{\mathrm{c}}$ & $7.23^{\mathrm{bc}}$ & $7.63^{\mathrm{b}}$ & $7.23^{\mathrm{b}}$ & $7.44^{\mathrm{c}}$ \\
\hline $\mathrm{N} 120$ & $8.71^{\mathrm{d}}$ & $7.92^{\text {cd }}$ & $8.55^{\mathrm{c}}$ & $8.10^{\mathrm{c}}$ & $8.34^{\mathrm{d}}$ \\
\hline $\mathrm{N} 150$ & $9.11^{\text {de }}$ & $8.58^{\text {de }}$ & $8.92^{\text {cd }}$ & $8.79^{\text {cd }}$ & $8.86^{\text {de }}$ \\
\hline N180 & $9.66^{\text {ef }}$ & $8.97^{\mathrm{ef}}$ & $9.50^{\text {de }}$ & $9.19^{\mathrm{d}}$ & $9.36^{\text {ef }}$ \\
\hline N210 & $9.93^{\mathrm{f}}$ & $9.21^{\mathrm{eg}}$ & $9.73^{\mathrm{e}}$ & $9.49^{\mathrm{d}}$ & $9.62^{\mathrm{f}}$ \\
\hline N240 & $9.98^{\mathrm{f}}$ & $9.37^{\mathrm{fg}}$ & $9.86^{\mathrm{e}}$ & $9.54^{\mathrm{d}}$ & $9.71^{\mathrm{f}}$ \\
\hline Average & $8.34^{\mathrm{A}}$ & $7.85^{\mathrm{B}}$ & $8.34^{\mathrm{A}}$ & $7.87^{\mathrm{B}}$ & $\times$ \\
\hline
\end{tabular}

a,b,c,d,e,f,g - yields labeled with different letters are significantly different in columns depending on N-rate

$\mathrm{A}, \mathrm{B}$ - yields labeled with different letters are significantly different depending on forecrop or soil tillage.

were obtained in Germany, where it was found that a higher wheat yield was obtained growing wheat after oilseed rape if compared with variant when wheat was grown after wheat (Sieling et al., 2005). Such a result could be confirmed also by the results of other studies, where oilseed crop in cereal-based cropping systems has shown to have a positive agronomic and economic impacts (Maadi et al., 2012). Study in Southern Italy showed that the continuous wheat cropping provided the lowest yield if compared with crop rotation (Montemurro \& Maiorana, 2014). Wheat growing in monoculture in three-year period reduced the yield by 20\% (Sieling et al., 2005).

Soil tillage also had a significant $(\mathrm{p}<0.001$; Table 2) impact on the grain yield increase $\left(+0.47 \mathrm{t} \mathrm{ha}^{-1}\right.$ in conventional tillage variant). Under reduced tillage system, the grain yield of winter wheat was lower (4.55 - $9.54 \mathrm{t} \mathrm{ha}^{-1}$ depending on N-rate) than under conventional tillage $\left(5.11-9.86 \mathrm{t} \mathrm{ha}^{-1}\right.$ depending on N-rate). This result does not conform to the findings from Lithuania, where it was found that the wheat grain yield was not significantly affected by different soil tillage methods (Seibutis, Deveikyte, \& Feiza, 2009). Winter wheat produced a higher grain yield in all fertilization variants when the traditional soil tillage was used (Table 1).

Considering the average grain yields in both years, nitrogen fertilization increased the grain yield after both forecrops and in both soil tillage systems. Similar results were obtained by Sieling et al. (2005), who found that nitrogen fertilization increased the grain yield after all forecrops.

\section{Yield components}

As wheat yield components, the number of ears per $1 \mathrm{~m}^{2}$, number and weight of grain per ear, 1000 grain weight were detected.

The number of ears per $1 \mathbf{~ m}^{2}$. Results show that nitrogen fertilizer significantly affected the number of ears per $\mathrm{m}^{2}$ (Table 2), and the increase of nitrogen

\section{Sums of squares showing the impact of researched factors on winter wheat yield and values of its components}

\begin{tabular}{|l|c|c|c|c|c|}
\hline \multirow{2}{*}{ Influencing factor } & \multicolumn{5}{|c|}{ Sums of squares } \\
\cline { 2 - 6 } & Yield & $\begin{array}{c}\text { Number of ears } \\
\text { per } 1 \mathrm{~m}^{2}\end{array}$ & $\begin{array}{c}\text { Grain number } \\
\text { per ear }\end{array}$ & $\begin{array}{c}\text { Grain weight per } \\
\text { ear }\end{array}$ & $\begin{array}{c}1000 \text { grain } \\
\text { weight }\end{array}$ \\
\hline N-fertilization rate & $570.39 * * *$ & $189499 * * *$ & $597.28^{* * *}$ & $2.93151^{* * *}$ & $134.160^{* * * *}$ \\
\hline Soil tillage & $8.99 * * *$ & $13269^{*}$ & $65.71^{*}$ & 0.06558 & 0.014 \\
\hline Forecrop & $14.48^{* * *}$ & 0.00 & 18.16 & 0.06412 & $60.086^{* * *}$ \\
\hline Year & 0.00 & 1406 & $440.38^{* * *}$ & $2.47749 * * *$ & $76.973 * * *$ \\
\hline Residuals & 74.05 & 250240 & 1044.88 & 2.15487 & 289.035 \\
\hline
\end{tabular}

$* \mathrm{p}<0.05 ; *{ }^{*} \mathrm{p}<0.01 ; * * \mathrm{p}<0.001$ 
The number of ears $\mathrm{m}^{-2}$ depending on nitrogen fertilizer rate, forecrop and soil tillage

\begin{tabular}{|c|c|c|c|c|c|}
\hline \multirow{2}{*}{ N-rate } & \multicolumn{2}{|c|}{ Forecrop } & \multicolumn{2}{|c|}{ Soil tillage } & \multirow{2}{*}{ Averag } \\
\hline & Oilseed rape & Wheat & Conventional & Reduced & \\
\hline N0 & $370^{\mathrm{a}}$ & $402^{\mathrm{a}}$ & $394^{\mathrm{a}}$ & $378^{\mathrm{a}}$ & $386^{\mathrm{a}}$ \\
\hline N60 & $436^{\mathrm{ab}}$ & $426^{a}$ & $428^{\mathrm{ab}}$ & $434^{\mathrm{ab}}$ & $431^{\mathrm{ab}}$ \\
\hline N90 & $463^{\mathrm{bc}}$ & $463^{\mathrm{a}}$ & $464^{\mathrm{ac}}$ & $462^{\mathrm{ac}}$ & $463^{\mathrm{bc}}$ \\
\hline N120 & $495^{\text {bd }}$ & $475^{\mathrm{a}}$ & $449^{\text {ad }}$ & $522^{\mathrm{bc}}$ & $485^{\text {bd }}$ \\
\hline N150 & $521^{\text {be }}$ & $523^{\mathrm{a}}$ & $512^{\text {bcde }}$ & $532^{\mathrm{bc}}$ & $522^{\text {cde }}$ \\
\hline N180 & $493^{\text {bf }}$ & $505^{\mathrm{a}}$ & $500^{\text {bcdf }}$ & $497^{\mathrm{bc}}$ & $499^{\text {bef }}$ \\
\hline $\mathrm{N} 210$ & $530^{\text {cdefg }}$ & $492^{\mathrm{a}}$ & $492^{\text {aef }}$ & $538^{\mathrm{bc}}$ & $512^{\mathrm{cdf}}$ \\
\hline N240 & $509^{\text {bg }}$ & $523^{\mathrm{a}}$ & $484^{\text {aef }}$ & $498^{c}$ & $516^{\text {cdf }}$ \\
\hline Average & $477^{\mathrm{A}}$ & $475^{\mathrm{A}}$ & $465^{\mathrm{A}}$ & $488^{\mathrm{B}}$ & $x$ \\
\hline
\end{tabular}

fertilizer rate also increased the number of ears per $1 \mathrm{~m}^{2}$ (Table 3). It is logical, as wheat tillering can continue also in spring, and $\mathrm{N}$ promotes it. The average number of winter wheat ears $\mathrm{m}^{-2}$ varied between $386-522$ per $1 \mathrm{~m}^{2}$ depending on the nitrogen fertilizer rate, and increase of it was observed up to the nitrogen fertilizer rate $\mathrm{N} 150$ (522 ears $\mathrm{m}^{-2}$; Table 3).

Forecrop in the trial did not significantly impact (Table 2) the average winter wheat number of ears $\mathrm{m}^{-2}$. At both forecrop variants, the average number of ears $\mathrm{m}^{-2}$ was similar (477 and 475 ; Table 3 ). This coincides with results of Lithuanian study which showed that crop rotation did not significantly affect the ear number per $1 \mathrm{~m}^{2}$ of winter wheat (Seibutis, Deveikyte, \& Feiza, 2009). Number of ears $\mathrm{m}^{-2}$ was similar in all the nitrogen fertilization variants when wheat after wheat was grown. Number of ears $\mathrm{m}^{-2}$ depended significantly on N-rate when wheat was grown after oilseed rape, and a significant increase, if compared with unfertilized control, was observed starting with N-rate $90 \mathrm{~kg} \mathrm{ha}^{-1}$. Further changes of ear number were slightly irregular.

Results showed a significant impact of soil tillage on the number of ears per $1 \mathrm{~m}^{2}(\mathrm{p}<0.05$; Table 2). It differs from results of Seibutis, Deveikyte, \& Feiza (2009) who found that soil tillage did not significantly affect the number of winter wheat ears $\mathrm{m}^{-2}$. Significantly higher $(\mathrm{p}<0.05)$ average number of ears $\mathrm{m}^{-2}$ was found using reduced soil tillage (488 ears) if compared to conventional soil tillage (465 ears). The number of ears $\mathrm{m}^{-2}$ gradually increased until nitrogen fertilizer rate N150 in both soil tillage variants. Using higher nitrogen fertilizer rates the number of ears $\mathrm{m}^{-2}$ decreased with only one exception - in the reduced soil tillage variant with $\mathrm{N}$-rate of $210 \mathrm{~kg} \mathrm{ha}^{-1}$ (Table 3).

Grain number per ear. Results show that nitrogen fertilizer rate had a significant impact on grain number per ear $(\mathrm{p}<0.001$; Table 2$)$. Grain number per ear ranged from 26.4 to 34.8 depending on the nitrogen fertilizer rate (Table 4). The results revealed that the lowest grain number per ear (26.4) was in the control variant where no nitrogen was applied, but the highest grain number per ear was observed in variants N180 (34.8) and N240 (34.6). The grain number per ear increased with each increment of nitrogen rate until N180 kg ha'- Similar results, where nitrogen significantly increased the number of grain per ear, were also obtained in the study of Usman et al. (2013). In literature it is mentioned that number of grain per ear is in direct connection with productivity of wheat. This component depends on genetics, environmental factors, and nutrition (Knežević et al., 2008). Change in the number of grain per ear can drastically influence the final yield (Protich, Todorovich, \& Protich, 2012).

Forecrop did not significantly influence the average grain number per ear of winter wheat. A slightly higher grain number per ear was observed when wheat was grown after wheat (32.2; Table 4), but significant differences at the $95 \%$ level were not found. Number of grain per ear increased up to the nitrogen fertilization rate of N180 under both forecrops.

Soil tillage showed a significant impact on grain number per ear $(\mathrm{p}<0.05$; Table 2$)$. Conventional soil tillage promoted a significantly higher $(\mathrm{p}<0.05)$ grain number per ear if compared to reduced soil tillage. Difference of average grain number per ear depending on tillage variant is 1.7 (Table 4).

Grain number per ear was significantly dependent on the trial year $(\mathrm{p}<0.001$; Table 2$)$. In the growing season 2014/2015 (35), the average grain number per ear was higher if compared with the growing season 2015/2016 (30.3). 
Table 4

Grain number per ear depending on nitrogen fertilizer rate, forecrop and soil tillage

\begin{tabular}{|l|c|c|c|c|c|}
\hline \multirow{2}{*}{ N-rate } & \multicolumn{2}{|c|}{ Forecrop } & \multicolumn{2}{c|}{ Soil tillage } & \multirow{2}{*}{ Average } \\
\cline { 2 - 5 } & Oilseed rape & Wheat & Conventional & Reduced & \\
\hline N0 & $26.0^{\mathrm{a}}$ & $26.7^{\mathrm{a}}$ & $25.9^{\mathrm{a}}$ & $26.9^{\mathrm{a}}$ & $26.4^{\mathrm{a}}$ \\
\hline $\mathrm{N} 60$ & $31.8^{\mathrm{a}}$ & $31.3^{\mathrm{ab}}$ & $33.2^{\mathrm{ab}}$ & $30.0^{\mathrm{a}}$ & $31.6^{\text {ab }}$ \\
\hline $\mathrm{N} 90$ & $29.8^{\mathrm{a}}$ & $30.8^{\mathrm{ac}}$ & $31.0^{\text {ac }}$ & $29.6^{\mathrm{a}}$ & $30.3^{\text {ac }}$ \\
\hline $\mathrm{N} 120$ & $31.9^{\mathrm{a}}$ & $32.7^{\text {ad }}$ & $33.2^{\text {ad }}$ & $31.3^{\mathrm{a}}$ & $32.3^{\text {bce }}$ \\
\hline $\mathrm{N} 150$ & $30.6^{\mathrm{a}}$ & $32.1^{\text {ae }}$ & $31.4^{\text {ae }}$ & $31.3^{\mathrm{a}}$ & $31.3^{\text {aed }}$ \\
\hline $\mathrm{N} 180$ & $34.4^{\mathrm{a}}$ & $35.2^{\text {bcdef }}$ & $36.2^{\text {bcdef }}$ & $33.0^{\mathrm{a}}$ & $34.8^{\text {bcd }}$ \\
\hline $\mathrm{N} 210$ & $32.3^{\mathrm{a}}$ & $34.5^{\text {afg }}$ & $34.4^{\text {afg }}$ & $32.0^{\mathrm{a}}$ & $33.3^{\text {bcd }}$ \\
\hline N240 & $34.1^{\mathrm{a}}$ & $35.0^{\text {bcdeg }}$ & $35.8^{\text {bcdeg }}$ & $33.3^{\mathrm{a}}$ & $34.6^{\text {bcd }}$ \\
\hline Average & $31.4^{\mathrm{A}}$ & $32.2^{\mathrm{A}}$ & $32.6^{\mathrm{A}}$ & $30.9^{\mathrm{B}}$ & $\times$ \\
\hline
\end{tabular}

a,b,c,de,f,g - yields labeled with different letters are significantly different in columns depending on N-rate

$\mathrm{A}, \mathrm{B}$ - yields labeled with different letters are significantly different depending on forecrop or soil tillage.

1000 grain weight. Wheat yield component showing the coarseness of grain is 1000 grain weight (TGW). TGW characterizes the quantity of nutrients in the grain. A large grain of wheat often has a higher germination energy. If the seeds contain more nutrients, they can develop stronger seedlings and build plants with a better-developed root system and stronger above soil-surface plant parts, - a result that leads to the higher grain yield (Protic et al., 2013).

Our results show that nitrogen fertilizer had a significant impact on the TGW ( $p<0.001$; Table 2$)$. The average 1000 kernel weight depending on the nitrogen fertilizer rates was $43.82-47.70 \mathrm{~g}$ (Table 5). It was observed that the increase of nitrogen fertilizer rate caused also increase of average TGW. This result coincides with another study in which it was also found that the increase of nitrogen rate significantly affected TGW (Skudra \& Ruža, 2016). Studies of Hussain et al. (2002) suggested that the maximum TGW was obtained using highest fertilizer rates (in this study three fertilizing rates were used: NPK 3525-25, 70-50-50 and 105-75-75 $\mathrm{kg} \mathrm{ha}^{-1}$ ). Low and medium fertilizer levels produced statistically similar TGW. Similar results were obtained also in our study. The highest average TGW was obtained applying the highest nitrogen dose (N240), but lowest - in control (N0). In variants where lower nitrogen fertilizer rates (N60, N90, N120) were applied the average obtained TGW were similar (Table 5).

Our results show that forecrop had a significant effect on TGW ( $p<0.001$; Table 2). Other authors found that crop rotation does not influence significantly TGW. But, in general, wheat produced in the rotation with lupin (Lupinus sp.) and oilseed rape produced

Table 5

1000 grain weight depending on nitrogen fertilizer rate, forecrop and soil tillage, $g$

\begin{tabular}{|l|c|c|c|c|c|}
\hline \multirow{2}{*}{ N-rate } & \multicolumn{2}{|c|}{ Forecrop } & \multicolumn{2}{c|}{ Soil tillage } & \multirow{2}{*}{ Average } \\
\cline { 2 - 5 } & Oilseed rape & Wheat & Conventional & Reduced & \\
\hline N0 & $44.27^{\mathrm{a}}$ & $43.38^{\mathrm{a}}$ & $43.92^{\mathrm{a}}$ & $43.73^{\mathrm{a}}$ & $43.82^{\mathrm{a}}$ \\
\hline N60 & $45.64^{\text {ab }}$ & $45.43^{\mathrm{a}}$ & $45.87^{\mathrm{a}}$ & $45.20^{\text {ab }}$ & $45.54^{\text {ab }}$ \\
\hline N90 & $46.08^{\text {ac }}$ & $45.63^{\mathrm{a}}$ & $45.79^{\mathrm{a}}$ & $45.91^{\text {ac }}$ & $45.85^{\text {ac }}$ \\
\hline N120 & $46.51^{\text {ad }}$ & $45.06^{\mathrm{a}}$ & $46.30^{\mathrm{a}}$ & $45.26^{\text {ad }}$ & $45.78^{\text {ad }}$ \\
\hline N150 & $47.99^{\text {bcd }}$ & $46.66^{\mathrm{a}}$ & $47.54^{\mathrm{a}}$ & $47.11^{\text {ae }}$ & $47.32^{\text {bcd }}$ \\
\hline N180 & $48.77^{\text {cd }}$ & $44.65^{\mathrm{a}}$ & $45.69^{\mathrm{a}}$ & $48.36^{\text {bcdef }}$ & $46.90^{\text {bcd }}$ \\
\hline N210 & $48.05^{\text {bcd }}$ & $46.09^{\mathrm{a}}$ & $47.45^{\mathrm{a}}$ & $46.80^{\text {afg }}$ & $47.16^{\text {bcd }}$ \\
\hline N240 & $49.03^{\mathrm{d}}$ & $46.38^{\mathrm{a}}$ & $47.62^{\mathrm{a}}$ & $47.79^{\text {bcdeg }}$ & $47.70^{\text {bcd }}$ \\
\hline Average & $47.04^{\mathrm{A}}$ & $45.41^{\mathrm{B}}$ & $46.27^{\mathrm{A}}$ & $46.21^{\mathrm{A}}$ & $\times$ \\
\hline
\end{tabular}

a,b,c,d,e,f,g - yields labeled with different letters are significantly different in columns depending on N-rate

$\mathrm{A}, \mathrm{B}$ - yields labeled with different letters are significantly different depending on forecrop or soil tillage. 
Grain weight per ear depending on nitrogen fertilizer rate, forecrop and soil tillage, $\mathrm{g}$

\begin{tabular}{|c|c|c|c|c|c|}
\hline \multirow{2}{*}{ N-rate } & \multicolumn{2}{|c|}{ Forecrop } & \multicolumn{2}{|c|}{ Soil tillage } & \multirow{2}{*}{ Averag } \\
\hline & Oilseed rape & Wheat & Conventional & Reduced & \\
\hline No & $1.03^{\mathrm{a}}$ & $1.09^{\mathrm{a}}$ & $1.09^{\mathrm{a}}$ & $1.04^{\mathrm{a}}$ & $1.06^{\mathrm{a}}$ \\
\hline N60 & $1.36^{\mathrm{ab}}$ & $1.32^{\mathrm{a}}$ & $1.40^{\mathrm{ab}}$ & $1.28^{\mathrm{ab}}$ & $1.34^{\mathrm{ab}}$ \\
\hline N90 & $1.35^{\mathrm{ac}}$ & $1.34^{\mathrm{a}}$ & $1.37^{\mathrm{ac}}$ & $1.32^{\mathrm{ac}}$ & $1.34^{\mathrm{ac}}$ \\
\hline N120 & $1.49^{\mathrm{bcd}}$ & $1.42^{\mathrm{a}}$ & $1.49^{\mathrm{ad}}$ & $1.42^{\mathrm{bc}}$ & $1.46^{\mathrm{bc}}$ \\
\hline N150 & $1.46^{\text {ade }}$ & $1.41^{\mathrm{a}}$ & $1.42^{\mathrm{ae}}$ & $1.46^{\mathrm{bc}}$ & $1.44^{\mathrm{bc}}$ \\
\hline N180 & $1.65^{\text {bee }}$ & $1.59^{\mathrm{a}}$ & $1.69^{\text {bcdef }}$ & $1.55^{\mathrm{bc}}$ & $1.62^{\mathrm{bc}}$ \\
\hline $\mathrm{N} 210$ & $1.60^{\text {bce }}$ & $1.56^{\mathrm{a}}$ & $1.60^{\mathrm{afg}}$ & $1.56^{\mathrm{bc}}$ & $1.58^{\mathrm{bc}}$ \\
\hline $\mathrm{N} 240$ & $1.71^{\text {bce }}$ & $1.53^{\mathrm{a}}$ & $1.63^{\text {bcdeg }}$ & $1.62^{\mathrm{bc}}$ & $1.62^{\mathrm{bc}}$ \\
\hline Average & $1.458^{\mathrm{A}}$ & $1.400^{\mathrm{A}}$ & $1.459^{\mathrm{A}}$ & $1.399^{\mathrm{A}}$ & $x$ \\
\hline
\end{tabular}

a,b,c,d,e,f,g - yields labeled with different letters are significantly different in columns depending on N-rate

$\mathrm{A}, \mathrm{B}$ - yields labeled with different letters are significantly different depending on forecrop or soil tillage.

grain with a higher TGW if compared to wheat grown in monoculture (Maali \& Agenbag, 2013). Our study results indicate that average TGW decreased when wheat was grown after wheat. A substantially higher TGW was obtained growing wheat after oilseed rape (Table 5).

Soil tillage did not significantly influence winter wheat TGW (Table 2). Similar results were obtained in another study (Cociu \& Alionte, 2011). In our study, the average TGW depending on soil tillage method was almost identical: in conventional tillage variant the average $\mathrm{TGW}$ was $46.27 \mathrm{~g}$, but in the reduced tillage variant $-46.21 \mathrm{~g}$. When the conventional soil tillage was used, average TGW did not depend on nitrogen fertilizer rate. In reduced soil tillage variant, a significant difference of TGW was observed between the control (43.73 g) variant (N0) and two fertilization variants: N180 (48.36 g) and N240 (47.79 g).

Statistical data processing shows that the trial year had a significant impact on the TGW $(\mathrm{p}<0.001$; Table 2). The average TGW of winter wheat was higher (47.42 g) in the growing season 2014/2015 if compared with the year 2015/2016 (45.62 g).

Grain weight per ear. Grain weight per ear is an important component of yield. A change in grain weight per ear drastically influences the final yield (Protić et al., 2013).

Applied nitrogen rate had a significant impact on grain weight per spike ( $p<0.001$; Table 2 ). The average grain weight per ear ranged from 1.06 to 1.62 $\mathrm{g}$ depending on the nitrogen fertilizer rate. The lower grain weight per ear was observed in control where no nitrogen was applied. The average grain weight per ear increased until nitrogen fertilizer rate N180, and at higher nitrogen fertilizer rates the grain weight per ear was similar to this or decreased (Table 6).
Results show that forecrop did not significantly affect $(p>0.05)$ the average grain weight per ear. A higher grain weight per ear was observed when oilseed rape was forecrop in all nitrogen application variants (Table 6). The smallest grain weight per ear in both forecrop variants was observed in control (N0; $1.03 \mathrm{~g}$ and $1.09 \mathrm{~g}$ when forecrops were oilseed rape and winter wheat, respectively), and then gradually increased with an increase of nitrogen rate up to the N180.

Soil tillage did not influence the grain weight per ear $(\mathrm{p}<0.05$; Table 2$)$. A higher grain weight per ear in all nitrogen fertilization variants was observed when the conventional soil tillage (1.09$1.69 \mathrm{~g})$ was used, but slightly lower - when reduced tillage $(1.04-1.62 \mathrm{~g})$ was used. In both tillage variants the grain weight per ear increased with an increase of nitrogen fertilizer rate: until the rate of N240 in reduced tillage variant, but in conventional soil tillage variant - until the rate N180.

Winter wheat grain weight per ear significantly differed depending on the growing year. The average grain weight per spike was significantly higher in 2014/2015 growing season (1.73 g) if compared to 2015/2016 (1.32 g). Three yield components (number of grain per ear, grain weight per ear and TGW) characterizing the individual plant productivity showed significantly higher values in 2014/2015.

\section{Conclusions}

1. Nitrogen fertilization increased the winter wheat grain yield after both forecrops and in both soil tillage variants. A significant average yield increase was obtained till the nitrogen fertilizer rate of N180; higher nitrogen fertilizer rates did not increase yield significantly. N-rate also significantly affected the values of all tested yield 
components: number of ears per $\mathrm{m}^{2}$, grain number per ear, 1000 grain weight (TGW), and grain weight per ear. An increase of yield component values was obtained by increasing N-rate up to N150 - N180 depending on specific component.

2. Forecrop had a significant impact on the wheat grain yield. Higher winter wheat yields were harvested when growing it after oilseed rape in comparison with wheat growing in resowings. Forecrop significantly influenced values of only one yield component - TGW.

3. Soil tillage method significantly influenced the winter wheat yield, and during the two-year $(2014 / 2015$ - 2015/2016) trial period higher yields were obtained by using conventional tillage (mould-board ploughing) if compared to reduced tillage (disk harrowing). Soil tillage variant significantly affected two evaluated yield components, but - number of ears per $\mathrm{m}^{2}$ was higher in the reduced tillage variant, while values of grain number per ear was higher in conventional tillage variant. Grain weight per ear and TGW were not significantly affected by the researched soil tillage variants.

\section{Acknowledgements}

Research is financed by the project 'Determination of maximal fertiliser norms for crops' which is carried out within the framework of 'State and European Union investment for encouragement in agriculture'.

\section{References}

1. Babulicová, M. (2014). The influence of fertilization and crop rotation on the winter wheat production. Plant Soil Environ. 60, 297 - 302.

2. Cociu, A.I., \& Alionte, E. (2011). Yield and some quality traits of winter wheat, maize and soybean, grown in different tillage and deep loosening systems aimed to soil conservation. Romanian Agricultural Research. 28, $109-120$.

3. Huang, W.Y., \& Uri, N.D. (1993). The effect of crop rotation on reducing excess nitrogen fertilizer use. Applied Mathematical Modelling. 17, 141 - 148. DOI: 10.1016/0307-904X(93)90039-J.

4. Hussain, M.I., Shah, S.H., Hussain, S., \& Iqbal, K. (2002). Growth, Yield and Quality Response of Three Wheat (Triticum aestivum L.) Varieties to Different Levels of N, P and K. International Journal of Agriculture \& Biology. 4, 362 - 364.

5. Knežević, D., Zečević, V., Mićanović, D., Madić, M., Paunović, A., Đukić, N., ... Jordačijević, S. (2008). Genetic analysis of number of kernels per spike in wheat (Triticum aestivum L.). Kragujeva Journal of Science. 28, $153-157$.

6. Kosutic, S., Filipovic, D., Gospodaric, Z., Husnjak, S., Kovacev, I., \& Copec, K. (2005). Effects of different soil tillage systems on yields of maize, winter wheat and soybean on albic luvisol in North-West Slavonia. Journal Central European Agriculture. 6, 241 - 248. DOI: 10.5513/jcea.v6i3.295.

7. Lyon, J.D., Stroup, W.W., \& Brown, R.E. (1998). Crop production and soil water storage in long-term winter wheat-fallow tillage experiments. Soil \& Tillage Research. 49, 19 - 27. DOI: 10.1016/S01671987(98)00151-2.

8. Maadi, B., Fathi, G., Siadat, S.A., Alami Saeid, K., \& Jafari, S. (2012). Effects of Preceding Crops and Nitrogen Rates on Grain Yield and Yield Components of Wheat (Triticum aestivum L.). World Applied Sciences Journal. 17 (10), 1331 - 1336.

9. Maali, S.H., \& Agenbag, G.A. (2013). Effect of soil tillage, crop rotation and nitrogen application rates on grain yield of spring wheat (Triticum aestivum L.) in the Swartland wheat producing area of the Republic of South Africa. South African Journal of Plant and Soil. 20(3), 111 - 118. DOI: $10.1080 / 02571862.2003 .10634919$.

10. Montemurro, F., \& Maiorana, M. (2014). Cropping systems, tillage and fertilization strategies for durum wheat performance and soil properties. International Journal of Plant Production. 8(1), 51 - 76.

11. Myrbeck, Å. (2014). Soil Tillage Influences on Soil Mineral Nitrogen and Nitrate Leaching in Swedish Arable Soils. Doctoral dissertation, Swedish University of Agricultural Sciences, Uppsala, Sweden.

12. Protic, R., Todorocoč, G., Protič, N., Kostič, M., Delic, D., Filipovič, M., ... Ugrenovič, V. (2013). Variation of grain weight per spike of wheat depending on variety and seed size. Romanian Agricultural Research. 30, $51-55$.

13. Protich, R., Todorovich, G., \& Protich, N. (2012). Grain weight per spike of wheat using different ways of seed protection. Bulgarian Journal of Agricultural Science. 18(2), 185 - 190.

14. Ruža, A., Maḷecka, S., \& Kreita, Dz. (2012). Slāpekḷa mēslojuma normu ietekme uz barības vielu izmantošanās rādītājiem ziemas kviešiem (The impact of nitrogen fertilizer norm on indicators of nutrient use for winter wheat). No Zinātniski praktiskā konference: zinātne Latvijas lauksaimniecības nākotnei: 
pārtika, lopbarība, šḳiedra un enerğija, 2012. g. 23. - 24. februāris (82. - 86. lpp.). Jelgava, Latvija: LLU. (in Latvian).

15. Seibutis, V., Deveikyte, I., \& Feiza, V. (2009). Effects of short crop rotation and soil tillage on winter wheat development in central Lithuania. Agronomy Research. 7, 471-476.

16. Sieling, K., Stahl, C., Winkelmann, C., \& Christen, O. (2005). Growth and yield of winter wheat in the first three years of a monoculture under varying $\mathrm{N}$ fertilization in NW Germany. European Journal of Agronomy. 22, 71 - 84. DOI: 10.1016/j.eja.2003.12.004.

17. Skudra, I., \& Ruža, A. (2014). Ziemas kviešu slāpekḷa papildmēslošanas veidu salīdzinājums integrētā audzēšanas sistēmā (Comparison of winter wheat nitrogen additional fertilizer form within the integrated plant nutrient management). No Zinātniski praktiskā konference: Līdzsvarota Lauksaimniecība, 2014. g. 20. - 21. februāris 2014 (30. - 34. lpp.). Jelgava, Latvija: LLU. (in Latvian).

18. Skudra, I., \& Ruža, A. (2016). Ziemas kviešu 1000 graudu masas un graudu tilpummasas ietekmējošo faktoru izvērtējums (Evaluation of factors affecting 1000 grain weight and volume weight of winter wheat). No Zinātniski praktiskā konference: Līdzsvarota Lauksaimniecība, 2016. g. 25. - 26. februāris (217. - 218. lpp.). Jelgava, Latvija: LLU. (in Latvian).

19. Stenberg, M. (1998). Soil tillage influences on nitrogen conservation. Retrieved February 20, 2017, from: http://www.vaxteko.nu/html/sll/slu/agraria/AGR129/AGR129.HTM.

20. Usman, K., Khan, E.A., Khan, N., Khan, M.A., Ghulam, S., Khan, S., \& Baloch, J. (2013). Effect of Tillage and Nitrogen on Wheat Production, Economics, and Soil Fertility in Rice-Wheat Cropping System. American Journal of Plant Sciences. 4, 17 - 25. DOI: 10.4236/ajps.2013.41004. 